\title{
ANALYSE OF THE CHALLENGES FOR SAFE TRANSITION FROM INDIVIDUAL INTRAOPERABLE RAILWAY SYSTEMS TO THE SINGLE EUROPEAN INTEROPERABLE RAILWAY SYSTEM
}

\section{PAWLIK ${ }^{1}$}

\begin{abstract}
Due to different reasons a significant modal shift from railway to road transport took place over last decades. The basic reasons are pointed in the paper introduction together with contradicting transport policy taking into account environmental and economical challenges. Political vision to stimulate modal shift from road and air to railway cannot become true without achieving railway technical and operational interoperability. Paper describes wide range of technical barriers between individual intraoperable railway systems in civil engineering structures, traction power supply, control command and signalling and the ways, which are being applied to ensure stepwise converging of the technical solutions taking into account safety and technical compatibility, as well as other essential requirements, namely: reliability, accessibility, health and environment.
\end{abstract}

Keywords: railway system, interoperability, intraoperability, railway civil engineering, traction power supply, control command and signaling, cross-acceptance, safety

\section{INTRODUCTION}

There is no doubt that a significant modal shift from railway to road transport occurred over last decades. The railway transport was invented and constructed vastly in the nineteen century. If railway development had not taken place, the nineteen century industrial revolution would have not be so successful, as rail transport had created backbone for national economies significantly complementing water based, see and inland waterways, transport links between different states.

\footnotetext{
${ }^{1}$ PhD., Eng., Railway Institute, 50 Chłopickiego street, 04-275 Warsaw, Poland, e-mail: mpawlik@ikolej.pl
} 
After the second world war industry, which was switched to, and developed for, production of the self-propelling military vehicles (motors, cars, trucks, tanks, ...) and their equipment (especially engines) was standing at the edge. As a result of political decisions this industry was reoriented to civil road vehicle production to minimize huge unemployment, which could cause economic crisis (similar to the one, which took place in 1920s and was seen as one of the reasons of the second world war). Need for individual car was created successfully. Growing number of road vehicles require intense development of road networks, which takes place since 1950s. Different factors which supported road transport success in the past, and which are supporting it nowadays can be pointed. Over years cars from being luxury goods become emanation of the development of the middle class in growing rich societies, to become now necessary home-ware like refrigerators. Roads are full of cars. Congestion is growing. Public transport is a must especially in growing agglomerations. Changes in organization of the industry from complete production in individual sites via sub-supplying of components and modules to globalization of the industry with extended supply chains, as well as changes in distribution from industrial stocks, warehouses and shops to just-in-time and door-to-door services has generated huge transport demand. To satisfy present needs transport have to be capable to offer such services disregarding localisation of shipping sites and destinations. That supports transport modes without technical barriers. Seamless ones, in which every vehicle is appropriate to be used at each piece of infrastructure. This is an environment, in which railway transport has to prove its usefulness.

\section{INTEROPERABILITY AND INTRAOPERABILITY}

\subsection{INTEROPERABILITY AND THE EUROPEAN NEW APPROACH TO MARKETING OF THE TECHNICAL SOLUTIONS}

Since 1996 European Union more and more pushes railway transport to satisfy present transport needs. In 1996 European parliamentarians accepted railway interoperability directive for high speed and in 2001 for conventional rail transport having in mind a set of solutions, which should be common for achieving seamless rail transport across internal European borders. Presently railway in the European Union is covered by directive dedicated to interoperability [1] and directive dedicated to railway safety [2]. A complete picture of the European and Polish requirements has been recently described in a joint publication issued last year [6]. 
Legally interoperability of the rail system is defined as "the ability of a rail system to allow the safe and uninterrupted movement of trains, which accomplish the required levels of railway lines' performance, and which depends on all regulatory, technical and operational conditions, which must be met in order to satisfy the essential requirements". The essential requirements are a key to understand the above statement and its consequences.

The essential requirements are directly linked with so called European 'new approach principles' used to define requirements for products and services, which are to be incorporated into common European market directly linked with the four European fundamental freedoms: the free movement of persons, services, capital and goods. In particular, it concerns the free movement of persons, including European-wide cross-acceptance of experts' competences, as well as free movement of goods, including European-wide cross-acceptance of products, in accordance with principle 'once accepted in whichever European member state - proven for the whole European market'.

For railway six essential requirements are defined: safety, reliability and availability, health, environmental protection, technical compatibility and accessibility. The way they have to be understood is defined in one of the annexes to the railway interoperability directive just on four pages. For instance to satisfy safety essential requirement for a whole railway system safety have to be ensured in five domains. Directive [1] namely states that:

- "The design, construction as well as assembly, maintenance and monitoring of safetycritical components, and more particularly of the components involved in train movements must be such as to guarantee safety at the level corresponding to the aims laid down for the network, including those for specific degraded situations.'

- The parameters involved in the wheel/rail contact must meet the stability requirements needed in order to guarantee safe movement at the maximum authorised speed. The parameters of brake equipment must guarantee that it is possible to stop within a given brake distance at the maximum authorised speed.

- The components used must withstand any normal or exceptional stresses that have been specified during their period in service. The safety repercussions of any accidental failures must be limited by appropriate means.

- The design of fixed installations and rolling stock and the choice of the materials used must be aimed at limiting the generation, propagation and effects of fire and smoke in the event of a fire. 
- Any devices intended to be handled by users must be so designed as not to impair the safe operation of the devices or the health and safety of users if used in a foreseeable manner, albeit not in accordance with the posted instructions."

to satisfy technical compatibility essential requirement directive requires that:

- "The technical characteristics of the infrastructure and fixed installations must be compatible with each other and with those of the trains to be used on the rail system."

The other essential requirements, namely reliability and health, as well as environment and accessibility are associated respectively with ensuring high quality of transport services and minimizing any risk for health of passengers, workers and citizens, as well as minimizing any risk for environment and ensuring railway transport accessibility for persons with reduced mobility (from people with small children to wheelchair users).

Railway system, as well as railway products and services can be considered as interoperable only if all applicable essential requirements are fulfilled. They are considered as being fulfilled when detailed requirements "regulatory, technical and operational conditions" are met. Therefore European Commission accepted as obligatory eleven Technical Specifications for Interoperability (TSIs) defining detailed requirements directly or indirectly e.g. by pointing respective European Norms (ENs) and European specifications [9].

Only products satisfying harmonized essential requirements can be put on the European Union market [4]. The EC certification proving that essential requirements are fulfilled is based on European conformity modules [3].

\subsection{INTRAOPERABILITY AND THE INDIVIDUAL STATES APPROACH TO THE RAILWAY RELATED TECHNICAL SOLUTIONS}

The essential requirements are fulfilled by existing railway systems of individual Member States of the European Union. There is no doubt that, in the light of national legal requirements, existing railways in France, in Germany, in Poland are safe, reliable, accessible and does not create unacceptable risk for health and environment. Moreover technical characteristics of the infrastructure and fixed installations are compatible with each other and with those of the trains, which are being used. The individual railway systems are also technically coherent, however coherency is only ensured on the territory of individual states. Therefore we cannot say that individual railway systems in individual countries are interoperable - they are not interoperable with each other. 
Looking on data transmission networks and namely on internet as a global harmonized data exchange standard and intranet being used as a standardized solution in restricted areas, e.g. by individual corporations, we can see some similarities. We can say that individual railway systems in individual Member States are intraoperable. They fulfil the essential requirements according to national requirements and utilise technical compatibility between all components, which are used within individual networks and rolling stock used in individual countries.

\subsubsection{DIFFERENTIATION OF THE RAILWAY TECHNICAL SOLUTIONS - ROLE IN THE STATES' DEFENCE POLICIES}

The development of the railway systems took place long time ago in other socio-political situation. Individual countries treated railway as quasi-military forces. Up to now, on special occasions, railway personnel is using uniforms. Railway ranks, which were used in the past the same way as military and police ones, still exist. Also railway management structures are similar to defence ones due to historical reasons. Armoured trains are no longer in use (now they are in North Korea only), but military legacy is still influencing present technical constrains.

In nineteen century countries constructing railways had to answer an important question - how to ensure, that our enemies, our neighbours, would not use our own railway lines and their railway vehicles to move their armies deeply into our territory, may be even up to our capital. Railways were welcomed, but had to be fully under state control. This is one of the reasons e.g. for different track gauges: $1668 \mathrm{~mm}$ on Iberian Peninsula, $1520 \mathrm{~mm}$ (originally $1524 \mathrm{~mm}$ ) and $1435 \mathrm{~mm}$ in between on vast part of the European territory.

\subsubsection{RAILWAY TECHNICAL SOLUTIONS ROLE IN NATIONAL ECONOMY - TRANSPORT BACKBONE AND SUPPORTING NATIONAL INDUSTRY}

Railways were welcomed first of all as a transport mode, which allows moving large amount of goods on relatively long distances. Rapidly growing need for production of electricity required construction of power plants. Coal based power plants require continuous supply of huge amount of coal. A single energy cell being constructed nowadays in Ostrołęka (1000 MW) requires twelve full length freight trains with coal daily. Development of railway transport was required for the development of the industry. In addition produced goods had to be moved into different locations. Components and sub-assemblies had to be supplied to final product production plants. Produced 
goods had to be transported to warehouses and shops. Railway transport constituted transport backbones of national economies.

Moreover constructing railway lines and production of the railway vehicles was creating additional need for transport. Steam locomotives also required coal, which had to be available along the railway lines. About one third of the transport by rail was dedicated to distribute coal along railway lines to ensure coal availability for steam locomotives. Railway electrification was therefore welcomed.

There are four main traction power supply systems which are in use on main railway lines: $1.5 \mathrm{kV}$ $\mathrm{DC}$ (direct current) and $3 \mathrm{kV} \mathrm{DC}$ as well as $15 \mathrm{kV} 16^{2 / 3} \mathrm{~Hz} \mathrm{AC}$ (alternating current) and $25 \mathrm{kV} 50$ $\mathrm{Hz}$ AC. Their application has created additional technical barrier, welcomed from military perspective. At the same time railway started to support national economies in another way. The dedicated technical solutions were developed for national railway by national industries. Huge public procurements were supporting national economies. The $15 \mathrm{kV} 16^{2} / 3 \mathrm{~Hz} \mathrm{AC}$ traction power supply system was developed by German industry for German railways, supported German economy and created additional technical difficulties on German borders. Presently overcoming such barriers is a challenge e.g. in relation to switching from $3 \mathrm{kV} \mathrm{DC}$ to $25 \mathrm{kV} 50 \mathrm{~Hz} \mathrm{AC} \mathrm{[8].}$

Coherence of railway technical solutions on the level of individual railway networks together with technical barriers at the borders seemed to be perfect solution. International railway transport was possible, but it was mainly based on moving non-traction vehicles over the borders. The train running from Moscow to Paris was hauling couches across five countries using five technically different locomotives each compatible with one of the five national networks.

Since 1970s development of the control command and signalling was supporting national industries and creating additional border barriers.

\subsection{NEED FOR TRANSITION FROM INTRAOPERABILITY TO INTEROPERABILITY}

Time has passed. Industry has changed its nature from national to international and global. World became smaller due to globalisation processes. Our neighbours, at least up to now in Europe, are no longer seen as our enemies. Road and air transport, which were developing in the last decades of the twenty century were not influenced so significantly by defence policies and by focusing on national industries.

A comparison between modes of transport was prepared by the European Union Agency for Railways in the scope of the works on so called $4^{\text {th }}$ Railway Package and recently presented in Poland [7]. On this basis usefulness of transport modes can be shown as below. 


\begin{tabular}{|c|c|c|c|c|c|}
\hline & $\begin{array}{c}\text { See } \\
\text { transport }\end{array}$ & $\begin{array}{c}\text { Railway } \\
\text { freight } \\
\text { transport }\end{array}$ & $\begin{array}{c}\text { Railway } \\
\text { passenger } \\
\text { transport }\end{array}$ & $\begin{array}{l}\text { Road } \\
\text { transport }\end{array}$ & $\begin{array}{c}\text { Air } \\
\text { transport }\end{array}$ \\
\hline Type of traffic & international & $\begin{array}{c}\text { national \& } \\
\text { international }\end{array}$ & mostly national & $\begin{array}{c}\text { national \& } \\
\text { international }\end{array}$ & international \\
\hline Legal framework & international & national $\left({ }^{*}\right)$ & national $\left({ }^{*}\right)$ & international & international \\
\hline National products & not required & required & required & not required & not required \\
\hline Operational rules & international & national $\left({ }^{*}\right)$ & national $\left({ }^{*}\right)$ & international & international \\
\hline $\begin{array}{l}\text { Usefulness for } \\
\text { supply chains }\end{array}$ & full & limited & limited & full & full \\
\hline
\end{tabular}

Fig. 1. Usefulness of different transport modes for supply chains

As can be seen road transport, air transport as well as see transport ensure coherence between transport means and transport infrastructure and utilise common rules and therefore can be seen as interoperable not only on the European level, while railway system is constituted by a set of intraoperable railway systems not forming an interoperable one.

\section{TECHNICAL CHALLENGES IN CONVERGING TECHNICAL SOLUTIONS}

Railway related legal framework and operational principles in the European Union are partly European. The Technical Specifications for Interoperability TSIs up to the end of 2014 were dedicated to TEN-T trans-European transport network only, which is e.g. in case of Poland one fourth of the railway network. Most of the investment projects were started before the end of 2014 and will be closed according to previous rules thanks to transitional provisions. European rules for railways system are therefore not applicable network wide. They are fully applicable in case of railway line upgrading projects which are starting after first January 2015 and in case of rolling stock which is being purchased after that date. However in operational circumstances trains cannot be subdivided into: ones running only on TEN-T, and ones running only outside TEN-T network. Interoperable trains must be coherent with existing infrastructure. Therefore infrastructure upgrading projects have to take into account technical compatibility with existing railway vehicles. Change in technical reality requires investments. Railway investments require relatively long time. Railway lines are not being closed for technical works. However line capacity is limited and other railway lines have to be used more intensively to serve traffic demand and therefore cannot be 
rebuild or upgraded at the same time. Safety must be ensured during transition from intraoperability to interoperability in all railway operational circumstanced including degraded modes of operation. Keeping technical compatibility during migration is also a must.

\subsection{OPEN POINTS AND SPECIFIC CASES IN TSIS}

Not everything what is seen as necessary for interoperability has been already agreed. The TSIs are pointing some open points. Not everything what is already agreed can be easily implemented. The TSIs are specifying some specific cases. Open points are summed up in dedicated annexes of the relevant TSIs. The amount of open points is decreasing, however some points are still open. If a point is open in the European legislation then national rules apply.

Some technical solutions are difficult to be changed due to technical or economical reasons. For such cases specific solutions are described in relevant TSIs as so called specific cases dedicated for directly pointed Member States. Specific cases are classified. Some are permanent, while some are temporary. For temporary ones time frames are given in TSIs.

\subsection{CROSS ACCEPTANCE OF TRAINS}

Railway infrastructure composed by railway lines and stations is being constructed for approximately 100 years and used even longer. Maintenance works of course have to take place, but they are not changing technical characteristic of the infrastructure. Railway trains are composed by railway vehicles, which are foreseen for approximately 40 years and used even longer.

Obtaining answer for the question about coherence of trains existing in one country with infrastructure existing in another neighbouring country is already urgent as trains have to run more and more over the borders especially within European Union. Nowadays, as in the past, many wagons are fulfilling international requirements and are proven for international traffic, small amount of couches are fulfilling national requirements of more than one country, very restricted amount of locomotives and multiple units are technically compatible with infrastructure in more than one country. Trains have to be coherent with infrastructure on each railway line they are foreseen to run. When train is not fully compliant with infrastructure, operation may be restricted or even not allowed. Therefore for many existing coaches, locomotives and multiple units verification of coherence with neighbouring infrastructure have to take place. For this purpose rolling stock cross acceptance rules have been defined. National technical requirements have been collected and are being analysed to judge about their equivalency. Infrastructure register is defined and is being 
filled with data to ensure easy accessible and complete information about restrictions imposed by infrastructure on specific lines and stations [5]. Rolling stock register is defined and is being filled with data for verifying compliance between vehicles and infrastructure.

\subsection{CROSS ACCEPTANCE OF COMPETENCES}

It is not enough to cross accept trains composed by cross accepted vehicles, as safety depends also on staff competences. Train drivers are required to satisfy health and competence requirements. For this reason the TSIs describing technical constrains for infrastructure, traction power supply and control command and signalling are supplemented with additional TSIs describing operational constrains. Signalling and operational rules are different in different countries. Train drivers have to pass for each country detailed exams proving their signalling and operational rules knowledge. For each railway line they have to obtain route knowledge. And last but not least they have to obtain documents proving their competences for each type of vehicle they are due to drive. And of course health proving and language competences proving are also fields of cross acceptance.

\subsection{DIFFERENTIATION IN SIGNALLING TECHNOLOGIES}

All signalling solutions (especially interlockings ensuring safety when trains are passing stations, block systems ensuring safety when trains are following each other on railway lines and level crossing protection systems ensuring safety at rail-road level crossings) are directly linked with operational rules, which are national. Use of national products is required. Differentiation of signal aspects is only an emanation of deep differences. Changing signalling rules would be extremely costly and would create unacceptable safety risk. Moreover changing operational rules in many cases is not possible without changing signalling equipment. As a result signalling solutions are out of scope of interoperability.

\subsection{DIFFERENTIATION IN CONTROL COMMAND TECHNOLOGIES}

On top of signalling equipment railways are using control command systems. Presently used systems are utilising electronic movement authorities. It is not possible to say exactly how many national control command systems are in use as some systems have more than one national version and some have many technical variants e.g. due to their development over long time. The national control command systems are treated as class B while a single class A system is already defined and 
named European Train Control System ETCS [9]. Signalling and operational rules are and will stay differentiated. Unification is taking place on control command level. Using multiple systems during transitional period is not the best way forward due to safety \& economy. Therefore dedicated specific transmission modules STMs have been elaborated and are available for on-board use.

\subsection{DIFFERENTIATION IN COMMUNICATION TECHNOLOGIES}

Similarly there are class B and class A communication systems. A single class A European system is already defined and named Global System for Mobile communication for Railways GSM-R. Class B systems are mostly dedicated to voice communication between dispatchers and train drivers. GSM-R is foreseen and used not only for voice communication but also for data transmission for the European Train Control System ETCS.

\subsection{INTEROPERABILITY AND INTRAOPERABILITY CONSTITUENTS}

Many products used for infrastructure, traction power supply and control command as well as for rolling stock construction are treated as products on a common European market and named Interoperability Constituents ICs e.g. slipers, rails and fastening systems. Additionally many products are treated as products on national markets. For instance tourouts, interlockings, trackside signals are national intraoperability constituents (and can be marked as nICs). ICs once accepted in whichever single member state of the EU are due to be accepted without additional proving in all member states of the EU. The ICs are defined functionally. Their interfaces are defined technically. Requirements are included in the EU legislation. The nICs are defined functionally in national legislation. Interoperability \& intraoperability conformity certificates and declarations are required.

\section{CONCLUSiOnS}

There is no doubt that railway lines will be interoperable after reconstruction within infrastructure upgrading projects. Such projects now cover in Poland only about ten percent of the railway network. In case of rolling stock generally new vehicles are the interoperable ones. Waiting would economically marginalize railway as a transport mode. Therefore quick changes are required.

Verification of the existing infrastructure conformity with TSIs is just starting on the basis of the data being collected for the infrastructure registers. Registers are due to cover whole railway infrastructure and all necessary information. The easy way is to point by number the certificates 
which are proving conformity with TSIs. In practice different types of restrictions have to be taken into account and different types of uncompliances have to be pointed. Without good infrastructure registers competition between different railway service providers is not possible. Without competition culture within railway, competition with other transport modes will not be focused. Registers are due to cover not only main lines but also sidings and industrial \& logistic centres.

Additionally so called 'safety culture' is seen as an obstacle on the way to interoperable railway defined by railway interoperability directive [1]. Risk and safety measures are defined by separate railway safety directive [2]. Under this directive six Common Safety Methods CSMs are defined. CSMs are defining requirements for safety certification of the railway operators and safety authorisation of the railway infrastructure managers. CSMs are defining safety monitoring rules and safety supervision rules. A separate CSM is defining common safety targets on the basis of the common safety indicators defined in the directive. Last but not least a separate CSM is defining risk assessment and acceptance criteria. This CSM is directly applicable to all safety challenges which are present during transition from a set of intraoperable national railway systems to a single European interoperable railway system.

\section{REFERENCES}

1. Directive 2008/57/EC of the European Parliament on the interoperability of the rail system within Community

2. Directive 2004/49/WE of the European Parliament on safety on the Community's railways

3. Commission Decision 2010/713/EU on modules for the procedures for assessment of conformity, suitability for use and EC verification to be used in the technical specifications for interoperability

4. Commission Recommendation 2014/897/EU on matters related to the placing in service and use of structural subsystems and vehicles under Directives 2008/57/EC and 2004/49/EC of the European Parliament

5. Commission Recommendation $2014 / 881 / \mathrm{EU}$ on the procedure for demonstrating the level of compliance of existing railway lines with the basic parameters of the technical specifications for interoperability

6. Joint publication, editor Pawlik M., "Interoperability of the railway system in the European Union, infrastructure, signalling, energy, rolling stock” („Interoperacyjność Systemu Kolei Unii Europejskiej, Infrastruktura, Sterowanie, Energia, Tabor”), KOW, Warsaw 2015, ISBN 978-83-943085-0-6

7. A. Harassek, "4th Railway Package - lifting the borders for competitive rail sector", 5th Advanced Rail Technologies International Conference, Warsaw 2016

8. A. Szelag, M. Patoka, "Some aspects of impact analysis of a planned new $25 \mathrm{kV}$ AC railway lines system on the existing $3 \mathrm{kV}$ DC railway system in a traction supply transition zone", SPEEDAM 2014, Ischia, Italy

9. European Railway Agency, "ERTMS/ETCS European Train Control System, System Requirements Specification", subset-026-1, issue 3.4.0, dated 12/05/2014

\section{LIST OF FIGURES:}

Fig. 1. Usefulness of different transport modes for supply chains

Rys. 1. Przydatność różnych rodzajów transport dla łańcuchów dostaw 


\section{ANALIZA WYZWAŃ DLA BEZPIECZNEGO PRZEJŚCIA OD INDYWIDUALNYCH INTRAOPERACYJNYCH KRAJOWYCH SYSTEMÓW KOLEJOWYCH DO JEDNEGO EUROPEJSKIEGO INTEROPERACYJNEGO SYSTEMU KOLEI}

Słowa kluczowe: kolej, interoperacyjność, intraoperacyjność, droga kolejowa, zasilanie trakcyjne, sterowanie i kontrola jazdy, wzajemna akceptacja, bezpieczeństwo

\section{STRESZCZENIE:}

Europejska Polityka transportowa od dwudziestu już lat zakłada secesję kolei jako ekonomicznie i środowiskowo cennego środka transportu. Tak się jednak nie dzieje, więc pytanie o przyczyny jest jak najbardziej zasadne. Artykuł wychodzi od powodów i uwarunkowań szybkiego rozwoju kolei w pierwszej połowie dwudziestego wieku by pokazać praprzyczyny dzisiejszego braku konkurencyjności kolei oraz wyzwania i rozwiązania proponowane i stosowane dla właściwego uwzględnienia kolei w zrównoważonym systemie transportu w Unii Europejskiej.

Szybki rozwój transportu kolejowego związany był z industrializacją. Miała ona jednak miejsce w określonej sytuacji, w której za naturalne i potrzebne uznawano powstające na granicach pomiędzy państwami, dziś tak kłopotliwe dla kolei, bariery techniczne. Bariery te występują w różnych obszarach. Dotyczą między innymi drogi kolejowej, na przykład szerokości toru czy skrajni. Dotyczą zasilania trakcyjnego począwszy od wartości napięcia i rodzaju prądu (stały lub przemienny) do zygzakowania sieci trakcyjnej. Dotyczą sterowania zarówno w zakresie warstwy podstawowej sterowania ruchem jak i systemów bezpiecznej kontroli jazdy i systemów łączności. Wszystkie te różnice infrastrukturalne przenoszą się na konstrukcje i wyposażenie taboru kolejowego skutkiem czego w poszczególnych krajach od lat do eksploatacji dopuszcza się tylko tabor zgodny z infrastrukturą kolejową danego kraju. Bariery występują także w zakresie procedur eksploatacji i ich powiązania z systemami sterowania. Idea jednego europejskiego systemu kolei wewnętrznie spójnego chociaż z wieloma zarządcami infrastruktury i z wieloma przewoźnikami została zaakceptowana przez europarlamentarzystów i określona jako interoperacyjność. Wprowadzanie interoperacyjności odbywa się zgodnie z tak zwanymi regułami horyzontalnymi definiującymi zasady funkcjonowania wspólnych europejskich rynków dla wyrobów i usług technicznych. Koncepcja ta opiera się na tak zwanych wymaganiach zasadniczych, które są spełniane dzięki stosowaniu uzgodnionych rozwiązań. Wymagania zasadnicze dla kolei to: bezpieczeństwo, niezawodność, przyjazność dla zdrowia i dla środowiska oraz zgodność techniczna i dostępność dla pasażerów. Wymagania takie dawno stawiały kolejom poszczególne państwa, ale były one spełniane w różnych państwach w różny sposób. Dlatego w uzupełnieniu europejskiej interoperacyjności gwarantowanej przez spełnienie wymagań zasadniczych dzięki stosowaniu europejskich rozwiązań artykuł definiuje intraoperacyjność gwarantowaną przez spełnienie tych samych wymagań zasadniczych dzięki stosowaniu rozwiązań krajowych. Pozwala to na uporządkowanie wyzwań i sposobów migracji od zbioru intraoperacyjnych systemów kolejowych poszczególnych krajów do interoperacyjnego europejskiego systemu kolei. Artykuł koncentruje się na bezpieczeństwie i zgodności technicznej. Uwzględnia punkty otwarte i szczególne przypadki w prawie europejskim, wzajemną akceptację pociągów i personelu technicznego, zróżnicowanie systemów sterowania, systemów łączności i systemów kontroli jazdy a także europejskie i krajowe tzw. 'wyroby z półki'. Pokazuje istniejące w tych obszarach możliwości migracji do rozwiązań docelowych wskazując jednocześnie na wyzwania w zakresie bezpieczeństwa i zgodności technicznej jakie występują w okresie przejściowym. 